\title{
Effectiveness of the Global Banking System in 2010: A Data Envelopment Analysis Approach*
}

\author{
Ngo Dang-Thanh \\ University of Economics and Business (Vietnam National University), Hanoi, Vietnam \\ Massey University, Palmerston North, New Zealand
}

\begin{abstract}
The current crisis has revealed the weaknesses of the global financial in general and its banking system in particular, and puts forward a requirement for assessing the effectiveness and stability of the banking sectors across countries. Based on available data from 64 countries over the world, the author tried to evaluate the effectiveness of the banking sectors in those countries through the view point of the data envelopment analysis approach to define how the global banking systems is under the effect of the current crisis. Findings from the research showed that banking systems in advanced economies are still more effective than in developing countries. Moreover, it explained the effect of the current financial crisis, the role of public finance (and the government), and the development of the (privately) commercial banks to the effectiveness of the banking sectors. The research also explained some determinants that can affect the effectiveness of the banking system, including inflation, bank concentration, and level of economic development.
\end{abstract}

Keywords: data envelopment analysis, effectiveness, efficiency, banking, cross countries

\section{Introduction}

Because of the important role of the banking and financial system in the rapid development of new industrial economies (NIEs) in the 1960s-1970s, there were renewed interests in the relationship between financial and economic growth. Schumpeter (1911) argued that the role of financial intermediaries in savings mobilization, projects evaluation and selection, risk management, entrepreneurs monitor, and facilitating transactions is important to technological innovation and economic growth. Following this argument, many other leading economists continuing emphasized the positively essential role of the financial sector in economic development, including Goldsmith (1969), Shaw (1973), McKinnon (1973), King and Levine (1993a, 1993b).

Banks are the core of the financial system. They accept deposits from savers and lend them to borrowers.

\footnotetext{
* Acknowledgement: The author would like to offer special thanks to Professor David Tripe at Centre for Banking studies, Massey University, New Zealand for his supports, encouragement and useful comments. The author also thanks participants at the 18th Annual Global Finance Conference in Bangkok, Thailand, April 2011 for their constructive comments and feedback to improve the quality of the paper. The usual disclaimer applies.

Ngo Dang-Thanh, Ph.D. candidate, Lecturer, Faculty of Political Economy, University of Economics and Business (Vietnam National University), Centre for Banking Studies, Massey University.

Correspondence concerning this article should be addressed to Ngo Dang-Thanh, Faculty of Political Economy, University of Economics and Business (Vietnam National University). E-mail: ndthanhf@yahoo.com.
} 
They hold liquid reserves which allowing predictable withdrawal demand. They issue liabilities which are more liquid than the deposits. They also reduce (or some times eliminate) the need of self-finance (Bencivenga \& Smith, 1991, p. 195). Banks hold an important role within the financial system, and to some certain level, researching the banking system therefore means researching the financial system.

Started from the bankruptcy of the Northern Rock Bank in the UK (2008, February), however, the global financial crisis and its heavily impacts have put researchers and policy makers under the requirement of re-assessment and re-evaluation the stability and performance of the global financial and banking system ${ }^{1}$.

A firm is effective when it reaches its target outputs. Similarly, a banking system is defined as effectiveness if it can fulfill its missions of providing banking services and monitoring the stability of the system. Meanwhile, if banking systems are set under similar conditions of macro- and micro-economic, the level of outcomes that a banking system can provide (in term of services and stability) is indeed its efficiency. In this sense, the problem of calculating effectiveness of banking systems all over the world becomes the problem of evaluating its efficiency with a (dummy) similar and equal input. This research is trying to define the effectiveness of the global banking system in 2010 through analysing cross-country data observed from 64 countries, using the data envelopment analysis (DEA) approach. The remainder of this paper is organized as follows. Section 2 gives some reviews on efficiency and effectiveness evaluation in the banking sector using DEA approach. Section 3 explains the methodologies and technical will be applied in the research. Section 4 shows empirical results and section 5 concludes.

\section{Literature Review}

To evaluate the efficiency of a set of firms (or banks), the most popular approaches are ratio analysis, parametric analysis and nonparametric analysis (the latter two methods belongs to the X-efficiency approach). While ratio analysis focuses on ratios between two variables (of inputs or outputs) to define the productivity and efficiency, X-efficiency analysis evaluates the efficiency of a bank through a multi-variables aspect.

DEA is a popular nonparametric method applied in evaluating efficiency in finance and banking area. After Farrell (1957) laid the foundation for a new approach in evaluating efficiency and productivity at micro-level, Charnes, Cooper and Rhodes (1978) and then Banker, Charnes and Cooper (1984) developed the CCR and BCC-DEA model, respectively, to evaluate the (relative) efficiencies of the researched decision making units (DMUs). Since then, DEA was increasingly applied in efficiency evaluation, especially in social sciences ${ }^{2}$.

There are a limited number of researches using DEA to examine banking performance at cross-country level. A study in 1997 showed that out of 130 studies on banking performance and efficiency, only six were focused on comparing the efficiency level of banking systems across countries (Berger \& Humphrey, 1997, pp. 182-184). As shown in Table 1, all three DEA studies were using small sample data at institutional (bank) level to define the benchmark frontier, hence, the global banking system was left untouched.

In the 2000s, further studies which used common frontier approach were developed by add in the model

\footnotetext{
${ }^{1}$ According to Science Direct, since 2010, there are more than 2,200 journal articles regarding banking performance after the crisis of 2007-2008 (Retrieved December 20, 2010, from http://www.sciencedirect.com).

2 Recent study of Avkiran (2010) showed that there are more than 170 articles using DEA as a main methodology to analyse the efficiency of banks and banks branches, including Sherman and Gold (1985), Peristiani (1997), Schaffnit, Rosen and Paradi (1997), and Pastor, Knox Lovell and Tulkens (2006).
} 
some environmental/controllable variables such as banking market conditions or market structure and regulation (Kwan, 2003; Lozano-Vivas, Pastor, \& Hasan, 2001; Maudos, Pastor, Perez, \& Quesada, 2002; Sathye, 2005). However, as they are also mainly focused on institutional level data while macro-environment is different from country to country, they ignored that banks which are efficient in this country may not performance well if they run as foreign-owned banks in other countries (Berger, 2007, p. 125). Hence, while trying to examine the whole banking systems across countries, this study attempts to overcome the above problem.

Table 1

Studies on Banking Performance at Cross-Country Level (Prior to 1997)

\begin{tabular}{|l|l|l|l|}
\hline \multicolumn{1}{|c|}{ Authors (date) } & \multicolumn{1}{c|}{ Method used } & \multicolumn{1}{c|}{ Countries included } & \multicolumn{1}{c|}{ Institution } \\
\hline $\begin{array}{l}\text { Berg, Forsund, Hjalmarsson, \& } \\
\text { Suominen (1993) }\end{array}$ & Data envelopment analysis & Norway, Sweden, Finland & Bank \\
\hline Fecher \& Pestieau (1993) & Distribution free approach & 11 OECD countries & Financial service \\
\hline Bergendahl (1995) & Mixed optimal strategy & Norway, Sweden, Finland, Denmark & Bank \\
\hline Ruthenberg \& Elias (1996) & Thick frontier approach & 15 developed countries & Bank \\
\hline Bukh, Berg, \& Forsund (1995) & Data envelopment analysis & Norway, Sweden, Finland, Denmark & Bank \\
\hline J. Pastor, Perez, \& Quesada (1997) & Data envelopment analysis & 08 developed countries & Bank \\
\hline
\end{tabular}

Note. Source: Berger and Humphrey (1997).

As DEA evaluates the efficiency of each DMU based on the optimal multipliers (or weights) of inputs and outputs factors, it allows us to examine the effectiveness of a banking system by looking at the achievements of the banking sector, including both quantity (assets, deposits, credits, etc.) and quality (overhead cost, nonperforming loans, frequency of bank crises, etc.) factors of commercial banks in the economy ${ }^{3}$. They are chosen following 122 variables represent the stability of the global financial system (WEF, 2010, Appendix A). However, since DEA treats those factors dynamically (meaning each country can have its own preference on them), to be understandable in evaluating and comparing the effectiveness of the banking systems between countries, a common preference (or common set of weights) for the above analyzed factors is required. Therefore, in this research, the DEA model will be divided into three stages, in which the first stage conducts a dynamic DEA model (DSW model) to define the relatively efficiencies of the banking systems from these 64 countries; the second stage examines the determinants affecting that efficiencies (Tobit model); and the third stage defines the common set of weights for those analyzed factors (CSW model) in order to conduct the final banking effectiveness scores.

\section{Technical Methodologies}

In the first step, DSW model is produced to calculate the maximum effectiveness scores that each country can achieve with the observed (achievement) factors. Mahlberg and Obersteiner (2001) and Depotis (2004) developed an input-oriented DEA-like model which treats all factors as outputs, while input is a dummy variable (values equal to 1 for all countries). Therefore, the DSW model in this research is in fact a constant-returns-to-scale (CRS) and input-oriented DEA model. For an evaluated country $j_{0}$-th, its efficiency score $\left(D S W j_{0}\right)$ can be expressed by the following non-negative linear problem:

\footnotetext{
${ }^{3}$ It is important to notice that these factors are outcomes that a banking system is aiming for; hence, the DEA model in this paper will use them all as output variables.
} 
Subject to:

$$
\operatorname{DSW}_{\mathrm{j}_{0}}=\max \frac{\sum u_{m} y_{m j_{0}}}{\sum v_{k} x_{k j_{0}}}
$$

$$
\begin{gathered}
\sum u_{m} y_{m j} \leq \sum v_{k} x_{k j}, 1 \leq j \leq n \\
\sum v_{k} x_{k j}=1 \\
\sum u_{m}=1 \\
u_{\mathrm{m}} \geq 0
\end{gathered}
$$

$x_{j}=1$ all original input values are assumed to be equal to 1 \}

where:

$u_{m}$ : weight of $m$-th output factor;

$v_{k}$ : weight of $k$-th input factor;

$x_{k j}: k$-th input of $j$-th country, $k=1$;

$y_{m j}: m$-th output of $j$-th country;

$n$ : number of countries;

$m$ : number of factors.

Due to the fact that some countries can have the same scores in this DSW model, a super efficiency DEA model (Zhu, 2001) is also ran to determine the ranking order of the researched countries, makes it easier to compare the effectiveness's of the banking systems between countries.

In the next step, a Tobit regression (for more details, see Tobin, 1958) is used to determine the factors affecting the country's banking efficiencies (Tobit model). Since the CSW scores are bounded between 0 to 1 , non-censored regression models could be biased (Fethi \& Pasiouras, 2010), while Tobit regression is justify as in equation (2). Variables used in this model are ones that mainly related to the financial efficient of a banking system at micro-level and are expressed in Table 2 .

$$
\begin{aligned}
E F= & \alpha+\beta 1 * C O N C+\beta 2 * R O A+\beta 3^{*} R O E+\beta 4^{*} C I R+\beta 5^{*} I N F \\
& +\beta 6^{*} C T A+\beta 7^{*} N I M+\beta 8^{*} C I I+\beta 9^{*} G R O U P
\end{aligned}
$$

Table 2

Variables of the Tobit Model

\begin{tabular}{|l|l|}
\hline Variables & Definition \\
\hline EF & CSW-DEA scores. \\
\hline CONC & Bank concentration (assets of three largest banks as a share of assets of all commercial banks). \\
\hline ROA & Bank's average return on assets (Net income/Total assets). \\
\hline ROE & Bank's average return on equity (Net income/Total equity). \\
\hline CIR & Bank's cost to income ratio (Total costs as a share of total income of all commercial banks). \\
\hline INF & Inflation, consumer prices (annual \%). \\
\hline CTA & Bank's capital to assets ratio (ratio of bank capital and reserves to total assets). \\
\hline NIM & Net interest margin of banks (value of bank's net interest revenue as a share of its interest-bearing assets). \\
\hline CII & $\begin{array}{l}\text { Depth of credit information index (measures rules and practices affecting the coverage, scope and accessibility of } \\
\text { credit information). }\end{array}$ \\
\hline GROUP & $\begin{array}{l}\text { Dummy variable of income group (equals to 0 if country belongs to lower income, 1 if middle income, and } 2 \text { if high } \\
\text { income group). }\end{array}$ \\
\hline
\end{tabular}


The last step is to define the optimal common set of weights which should be used for compare and ranking countries based on their banking systems' effectiveness. It is done by applying the CSW model. It is believed that the efficient frontier found in the DSW model in the first step is the "best practice frontier" (Grosskopf \& Valdmanis, 1987; Schaffnit, Rosen, \& Paradi, 1997); hence, the optimal common weight set will be the one that get every countries' performances closest to that frontier. There are several ways to define that common set of weights is based on this idea. While imposing bounds for factor weights, Roll and Golany (1993) found out that the common set of weights can be defined by maximizing the average efficiency of all DMUs or maximizing the number of efficient DMUs. Kao and Hung (2005) applied a compromise solution approach to minimize the total squared distances between the optimal objective values (found by DEA) and the common weighted values (found by using common set of weights). Jahanshahloo, Memariani, Lotfi and Rezai (2005) applied the multiple objective programming approach to simultaneously maximize the performance scores to get it closes to the "best practice frontier". Liu and Peng (2008) applied the common weights analysis to minimize the vertical and horizontal virtual gaps between the benchmark line (slope equals to 1.0, or performance scores equal to 1.0) and the coordinate of common weighted DMUs. In this paper, we modified the model of Kao and Hung (2005) into a minimum distance efficiencies model, in which the common set of weights can be defined as the one minimizing the total distances between optimal efficiencies (DSW scores) and common weighted scores (CSW scores) of all DMUs, under the condition that each DMU's efficiency cannot exceed its DSW efficiency ${ }^{4}$. To understand the role of each factor in CSW scores, another condition was added where the total sum of weights is equal to 1 (or $100 \%$ ). The country's banking effectiveness scores will be constructed based on that CSW scores and findings from the super efficiency DEA results in the previous step. This CSW model can be expressed as a non-negatively linear problem as follows:

$$
\min \sum\left(e_{j}^{*}-e_{j}\right)
$$

Subject to:

$$
\begin{gathered}
e_{j}^{*}=\mathrm{DSW}_{\mathrm{j}} \\
e_{j}=\frac{\sum u_{m} y_{m j}}{\sum v_{k} x_{k j}}, 1 \leq j \leq n \\
e_{j} \leq e_{j}^{*} \\
\sum v_{k} x_{k j}=1 \\
\sum u_{m}=1 \\
u_{m} \geq 0.01^{5}
\end{gathered}
$$

$x_{j}=1$ all original input values are assumed to be equal to 1$\}$

where:

$u_{m}$ : weight of $m$-th factor;

$y_{m j}: m$-th factor of $j$-th country;

\footnotetext{
${ }^{4}$ This constrain makes these distances non-negative, hence, they can be used directly rather than the squared distances.

${ }^{5}$ Mahlberg and Obersteiner (2001) found that restriction weights with lower bound of 0.01 steered a middle course between too strong predetermination and too large flexibility.
} 
$n$ : number of countries;

$m$ : number of factors.

The final effectiveness scores will then be calculated following this equation:

$$
E S_{j}=\sum u_{m}^{C S W} y_{m j}
$$

where:

$E S_{j}$ : Effectiveness score of country $j$-th;

$u_{m}{ }^{C S W}$ : Common weight of factor $m$-th;

$y_{m j}$ : Value of factor m-th of country $j$-th.

\section{Empirical Results}

In the first stage, countries and factors are collected from the database of Beck, Demirgüç-Kunt and Levine (2000), Laeven and Valencia (2010), the World Bank (World Development Indicator, Global Development Financial, and Doing Business databases), the International Monetary Fund (IMF, 2010), the Consultative Group to Assist the Poor (CGAP, 2010) and Annual Reports from Central Banks of such researched countries. Ten factors $^{6}$ are included in this research, covering both quantitative (the first 5 factors) and qualitative (the last 5 factors) aspect of the banking sectors (see Table 3). It is important to notice that the last 3 factors are undesirable factors (as they have negative effect to the banking effectiveness), hence, they was transformed into desirable ones through the linear monotone decreasing transformation method ${ }^{7}$.

Table 3

Descriptive Statistics of Factors

\begin{tabular}{|c|c|c|c|c|c|}
\hline Factors & Mean & $\begin{array}{l}\text { Standard } \\
\text { error }\end{array}$ & $\begin{array}{l}\text { Standard } \\
\text { deviation }\end{array}$ & Minimum & Maximum \\
\hline Commercial banks' assets/GDP & 0.74 & 0.06 & 0.48 & 0.09 & 2.42 \\
\hline Domestic credit provided by banking sector (\% of GDP) & 80.21 & 8.74 & 69.92 & -11.17 & 379.30 \\
\hline Commercial banks' deposits/GDP & 0.60 & 0.04 & 0.36 & 0.12 & 1.80 \\
\hline Number of ATMs per 100,000 people & 28.27 & 4.87 & 38.96 & 0.06 & 236.07 \\
\hline Number of branches per 100,000 people & 11.47 & 1.23 & 9.86 & 0.53 & 45.60 \\
\hline Private credit bureau coverage ( $\%$ of adults) & 36.72 & 4.38 & 35.03 & 0 & 100 \\
\hline Public credit bureau coverage ( $\%$ of adults) & 8.24 & 1.60 & 12.76 & 0 & 48.50 \\
\hline Banks' overhead costs/Total assets & 0.22 & 0.01 & 0.05 & 0 & 0.26 \\
\hline Nonperforming loans ratios of commercial banks & 17.39 & 0.78 & 6.23 & 0 & 22.80 \\
\hline Frequency of banking crises & 2.92 & 0.09 & 0.72 & 0 & 4.00 \\
\hline
\end{tabular}

Note. Data of the last three variables are already transformed.

As mentioned in section 3, those factors will be treated as output variables, while a dummy-input (equals to 1) will be set for the whole 64 countries. The DSW model then produces an effective frontier built from 25 countries, while the other 39 are ineffective (see Appendix A Table A2).

Within the ineffective ones, none of them is developed countries, suggesting that the banking systems in

\footnotetext{
${ }^{6}$ According to Dyson et al. (2001, p. 248) and Avkiran (2001, p. 68), one rule of thumb in using DEA is that the sample size has to be at least 3 times bigger than the number of total inputs and outputs to overcome the discrimination problem. As we have 64 samples over 10 variables, hence, this research is justified.

${ }^{7}$ In this method, the transformed values will be calculated by the difference between a proper translation vector $w$ with the original values of those undesirable factors. For more details, see Seiford and Zhu (2002) and Fare and Grosskopf (2004).
} 
advanced economies still run better than in developing countries although they had to bear stronger effect from the current crisis. This can be explained by the difference between projected values and original values of these factors (in percentage of original values), in which the biggest differences are mainly for quantity factors, except for the case of private credit bureau coverage. The results show that, major weaknesses of ineffective countries in banking system development are the ATM network, bank deposits to GDP, private credit coverage, bank assets, and bank's domestic credits. Those are the disadvantage of developing countries as they are still on their way developing their financial and banking systems (see Table 4).

Table 4

Differences Between Projected and Original Values for Inefficient Countries

\begin{tabular}{lcc}
\hline \multirow{2}{*}{ Factors } & & Total differences \\
\cline { 2 - 3 } & In value & In percentage of original value \\
\hline Commercial banks' assets/GDP & 21.72 & 45.56 \\
Domestic credit provided by banking sector (\% of GDP) & 2,338 & 45.55 \\
Commercial banks' deposits/GDP & 21.67 & 56.44 \\
Number of ATMs per 100,000 people & 1,373 & 75.88 \\
Number of branches per 100,000 people & 379.4 & 51.7 \\
Private credit bureau coverage (\% of adults) & 1,230 & 52.34 \\
Public credit bureau coverage (\% of adults) & 56.46 & 10.71 \\
Banks' overhead costs/Total assets & 0.741 & 5.376 \\
Nonperforming loans ratios of commercial banks & 80.16 & 7.201 \\
Frequency of banking crises & 21.68 & 11.59 \\
Average & 552.3 & 36.24 \\
\hline
\end{tabular}

In the second stage, the results from Tobit model show the relation between the banking systems' effectiveness and various variables such as inflation level of the economy, income group that the country belongs to, concentration of the banking system, etc., as summarized in Figure 1. It is obvious that higher inflation, banking concentration, and bank's cost-income ratio can reduce the effectiveness of the banking sector (respectively significant at 1,5 and 10 percent), while the high level of economic development (improving to higher income group) can help increase the effectiveness of the banking system ( $5 \%$ significant level).

\begin{tabular}{|c|c|c|c|c|c|c|}
\hline \multicolumn{4}{|c|}{$\begin{array}{l}\text { Tobit regression } \\
\text { Log 7ikelihood = }\end{array}$} & \multicolumn{2}{|c|}{$\begin{array}{l}\text { Number of obs } \\
\text { LR chi2 (9) } \\
\text { Prob > Chiz } \\
\text { Pseudo R2 }\end{array}$} & \multirow{2}{*}{$\begin{array}{r}51 \\
29.02 \\
0.0006 \\
-0.6694 \\
\text { Interva1] }\end{array}$} \\
\hline$E F$ & coef. & std. Err. & $t$ & $P>|t|$ & [95\% conf. & \\
\hline $\begin{array}{l}\text { CONC } \\
\text { ROA } \\
\text { ROE } \\
\text { CIR } \\
\text { INF } \\
\text { CTA } \\
\text { NIM } \\
\text { CII } \\
\text { GROUP } \\
\text { _CONS }\end{array}$ & $\begin{array}{r}-.1178702 \\
-.000442 \\
-.029139 \\
-.0367652 \\
-.0071183 \\
-.0072785 \\
-3790703 \\
-.007743 \\
-0465285 \\
1.126271\end{array}$ & $\begin{array}{r}.0534656 \\
-0006043 \\
.0565369 \\
.0217527 \\
.00253 \\
.0029542 \\
.2781161 \\
.0066039 \\
.0190049 \\
.0879408\end{array}$ & $\begin{array}{r}-2.20 \\
-0.73 \\
-0.52 \\
-1.69 \\
-2.81 \\
-2.46 \\
1.36 \\
-1.17 \\
2.45 \\
12.81\end{array}$ & $\begin{array}{l}0.033 \\
0.469 \\
0.609 \\
0.098 \\
0.007 \\
0.018 \\
0.180 \\
0.248 \\
0.019 \\
0.000\end{array}$ & $\begin{array}{r}-.2257683 \\
-.0016614 \\
-.1432352 \\
-.080664 \\
-.012224 \\
-.0132402 \\
-.1821907 \\
-.0210702 \\
-0081751 \\
-.9487993\end{array}$ & $\begin{array}{r}-0099722 \\
-0007775 \\
-0849572 \\
-0071335 \\
-.0020126 \\
-.0013167 \\
-9403313 \\
-0055842 \\
-0848819 \\
1.303743\end{array}$ \\
\hline /sigma & .062421 & .0079119 & & & .0464541 & .0783879 \\
\hline obs. summar & $\begin{array}{r}0 \\
35 \\
16\end{array}$ & 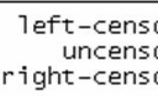 & $\begin{array}{l}d \text { obs } \\
\text { d abs }\end{array}$ & $\begin{array}{l}\text { rations } \\
\text { rations } \\
\text { rations at }\end{array}$ & $E F>=\mathbf{1}$ & \\
\hline
\end{tabular}

Figure 1. Determinants of the global banking effectiveness. 
In the last stage, solving the non-linear problem of the CSW model (equation (3)) helped us defining a common set weight for the ten factors of every country in the research (see Table 5). Noticeably, important factors which strongly affect the performance of the banking sector in those countries are non-performing loans ratio (79.49\%), public credit bureau coverage (10.47\%), and number of branches per 100,000 people (3.03\%). The other factors only keep minimum role (1\% weight) in the final results. It shows that the effectiveness of the banking sector is mainly affected by the damage of the global crisis, the (financial) public policy of the government, and the development of the commercial bank system of each country respectively. It also suggests that the quality of the banking sector is now becoming more important than the quantity aspect, not only for countries with developed banking systems but for developing countries as well. Thus, country which focuses on improving the quality of its banking sector can have higher effectiveness and is more stable.

Table 5

Common Set of Weights for the Effectiveness Scores

\begin{tabular}{lc}
\hline Factors & Weight \\
\hline Commercial banks' assets/GDP & 1.00 \\
Domestic credit provided by banking sector (\% of GDP) & 1.00 \\
Commercial banks' deposits/GDP & 1.00 \\
Number of ATMs per 100,000 people & 1.00 \\
Number of branches per 100,000 people & 3.03 \\
Private credit bureau coverage (\% of adults) & 1.00 \\
Public credit bureau coverage (\% of adults) & 10.47 \\
Banks' overhead costs/Total assets & 1.00 \\
Nonperforming loans ratios of commercial banks & 79.49 \\
Frequency of banking crises & 1.00 \\
\hline
\end{tabular}

By applying this common set of weights, the effectiveness scores of country's banking systems can be calculated and countries can be ranked as in Table 6. Since non-performing loans ratio became the most important factor, countries having problems with NPLs became less efficient and ranked bottom in the list, including even Denmark and New Zealand.

Table 6

The Global Banking Effectiveness in 2010

\begin{tabular}{|c|c|c|c|c|c|}
\hline Rank & Country & Effectiveness score & Rank & Country & Effectiveness score \\
\hline 1 & Japan & 23.231 & 33 & Kuwait & 17.606 \\
\hline 2 & Canada & 23.231 & 34 & Venezuela, RB & 17.556 \\
\hline 3 & Chile & 23.231 & 35 & Moldova & 17.504 \\
\hline 4 & Malaysia & 22.275 & 36 & Lithuania & 17.394 \\
\hline 5 & Australia & 22.177 & 37 & Bolivia & 17.333 \\
\hline 6 & Switzerland & 22.079 & 38 & Croatia & 17.307 \\
\hline 7 & United States & 22.037 & 39 & Uganda & 16.947 \\
\hline 8 & Bulgaria & 21.755 & 40 & Jordan & 16.891 \\
\hline 9 & Argentina & 21.671 & 41 & Mozambique & 16.853 \\
\hline 10 & Ecuador & 21.461 & 42 & Poland & 16.771 \\
\hline 11 & Costa Rica & 21.421 & 43 & Colombia & 16.770 \\
\hline 12 & United Kingdom & 21.415 & 44 & Armenia & 16.276 \\
\hline
\end{tabular}




\begin{tabular}{|c|c|c|c|c|c|}
\hline Rank & Country & Effectiveness score & Rank & Country & Effectiveness score \\
\hline 13 & Korea, Rep. & 21.066 & 45 & Thailand & 16.203 \\
\hline 14 & Sweden & 21.060 & 46 & Russian Federation & 16.066 \\
\hline 15 & Brazil & 20.968 & 47 & Georgia & 15.859 \\
\hline 16 & El Salvador & 20.232 & 48 & Morocco & 15.475 \\
\hline 17 & Dominican Republic & 20.070 & 49 & Kazakhstan & 15.288 \\
\hline 18 & Peru & 19.907 & 50 & Albania & 15.116 \\
\hline 19 & Israel & 19.735 & 51 & Yemen, Rep. & 14.566 \\
\hline 20 & Guatemala & 19.626 & 52 & Nigeria & 14.202 \\
\hline 21 & Singapore & 19.326 & 53 & Kenya & 11.871 \\
\hline 22 & Estonia & 19.276 & 54 & Bangladesh & 10.486 \\
\hline 23 & Panama & 19.085 & 55 & Tunisia & 9.696 \\
\hline 24 & Indonesia & 18.993 & 56 & Romania & 9.442 \\
\hline 25 & Turkey & 18.749 & 57 & Egypt, Arab Rep. & 8.051 \\
\hline 26 & South Africa & 18.538 & 58 & Mauritius & 7.601 \\
\hline 27 & Czech Republic & 18.302 & 59 & Denmark & 6.519 \\
\hline 28 & Hungary & 18.233 & 60 & New Zealand & 5.338 \\
\hline 29 & Saudi Arabia & 18.045 & 61 & Vietnam & 4.841 \\
\hline 30 & India & 17.921 & 62 & Angola & 4.761 \\
\hline 31 & Macedonia, FYR & 17.842 & 63 & Botswana & 0.662 \\
\hline 32 & Slovak Republic & 17.750 & 64 & Sierra Leone & 0.203 \\
\hline
\end{tabular}

\section{Conclusions}

Using data from 64 countries in the world, this research applied the data envelopment analysis (DEA) to evaluate the effectiveness of banking systems in the World in 2010. The research was divided into three steps, in which the first stage applied data envelopment analysis method to build a common frontier for these 64 countries; the second step detected the determinants of the banking sector's effective; and the last step defined a common set of weights for analyzing factors helping in ranking the effectiveness of the global banking system in 2010 .

The research evaluated the effectiveness of the global banking systems using a dummy input and ten outputs to create a common frontier for the whole banking systems of 64 countries (while previous studies used institutional level data of smaller sample size); and after that building a common set of weights to calculate the effectiveness scores of the global banking system, applied to the DEA method. This proposes an interesting function for using DEA in examining the effectiveness (and efficiency) in the banking sector.

Findings from the research showed that banking systems in advanced economies are still more effective than in developing countries. Reasons seem to be related to the development of the banking sector in quantity (number of bank branches) and more importantly in quality aspects (including the NPL ratio, public credit bureau coverage, bank concentration, bank's capital, and cost-income ratio). It is also included the effect of economic development, expresses through level of income (group) and inflation rates. These results partly explained the effect of the current financial crisis to the banking sector, the role of public finance (and the government) in this kind of situation, and the important role of developing commercial banking system to its efficiency and effectiveness.

\section{References}

Avkiran, N. K. (2001). Investigating technical and scale efficiencies of Australian universities through data envelopment analysis. 
Socio-Economic Planing Sciences, 35, 57-80.

Avkiran, N. K. (2010). Association of DEA super-efficiency estimates with financial ratios: Investigating the case for Chinese banks. Omega, 39, 323-334.

Banker, R. D., Charnes, A., \& Cooper, W. W. (1984). Some models for estimating technical and scale inefficiencies in data envelopment analysis. Management Science, 30(9), 1078-1092.

Beck, T., Demirgüç-Kunt, A., \& Levine, R. (2000). A new database on financial development and structure. World Bank Economic Review, 14, 597-605.

Bencivenga, V. R., \& Smith, B. D. (1991). Financial intermediation and endogenous growth. Review of Economic Studies, 58, 195-209.

Berg, S. A., Forsund, F. R., Hjalmarsson, L., \& Suominen, M. (1993). Banking efficiency in the Nordic countries. Journal of Banking and Finance, 17, 371-388.

Bergendahl, G. (1995). DEA and benchmarks for Nordic banks. Working paper. Gothenburg University, Gothenberg, Sweden.

Berger, A. N. (2007). International comparison of banking efficiency. Financial Markets, Institutions and Instruments, 16(3), 119-144.

Berger, A. N., \& Humphrey, D. B. (1997). Efficiency of financial institutions: International survey and directions for future research. European Journal of Operational Research, 98, 175-212.

Bukh, P. N. D., Berg, S. A., \& Forsund, F. R. (1995). Banking efficiency in the Nordic countries: A four-country Malmquist index analysis. University of Aarhus, Denmark.

CGAP. (2010). Financial access 2010: The state of financial inclusion through the crisis. Washington, D.C.: Consultative Group to Assist the Poor.

Charnes, A., Cooper, W. W., \& Rhodes, E. (1978). Measuring the efficiency of decision making units. European Journal of Operational Research, 2, 429-444.

Depotis, D. (2004). A reassessment of the human development index via data envelopment analysis. Journal of Operational Research Society, 1-12.

Dyson, R. G., Allen, R., Camanho, A. S., Podinovski, V. V., Sarrico, C. S., \& Shale, E. A. (2001). Pitfalls and protocols in DEA. European Journal of Operational Research, 132, 245-259.

Fare, R., \& Grosskopf, S. (2004). Modeling undesirable factors in efficiency evaluation: Comment. European Journal of Operational Research, 157, 242-245.

Farrell, M. J. (1957). The measurement of productive efficiency. Journal of the Royal Statistical Society, 120(3), 253-281.

Fecher, F., \& Pestieau, P. (1993). Efficiency and competition in O.E.C.D. financial services. In H. O. Fried, C. A. K. Lovell, \& S. S. Schmidt (Eds.), The measurement of productive efficiency: Techniques and applications (pp. 374-385). Oxford University Press, UK.

Fethi, M. D., \& Pasiouras, F. (2010). Assessing bank efficiency and performance with operational research and artificial intelligence techniques: A survey. European Journal of Operational Research, 204, 189-198.

Goldsmith, R. W. (1969). Financial structure and development. New Haven, C.T.: Yale University Press.

Grosskopf, S., \& Valdmanis, V. (1987). Measuring hospital performance: A non-parametric approach. Journal of Health Economics, 6, 89-107.

IMF. (2010). Global financial stability report: Sovereigns, funding, and systemic liquidity. Washington, D.C.: International Monetary Fund.

Jahanshahloo, G. R., Memariani, A., Lotfi, F. H., \& Rezai, H. Z. (2005). A note on some of DEA models and finding efficiency and complete ranking using common set of weights. Applied Mathematics and Computation, 166, 265-281.

Kao, C., \& Hung, H. T. (2005). Data envelopment analysis with common weights: the compromise solution approach. Journal of Operational Research Society, 56, 1196-1203.

King, R. G., \& Levine, R. (1993a). Finance and growth: Schumpeter might be right. Quarterly Journal of Economics, 108, 717-737.

King, R. G., \& Levine, R. (1993b). Finance, entrepreneurship, and growth: Theory and evidence. Journal of Monetary Economics, $32,513-542$.

Kwan, S. H. (2003). Operating performance of banks among Asean economies: An international and time series comparison. Journal of Banking and Finance, 27, 471-489.

Laeven, L., \& Valencia, F. (2010). Resolution of banking crises: The good, the bad, and the ugly. IMF Working paper 10/146.

Liu, F. H. F., \& Peng, H. H. (2008). Ranking units of the DEA frontier with common weights. Computers and Operations Research, 35, 1624-1637. 
Lozano-Vivas, A., Pastor, J. T., \& Hasan, I. (2001). European bank performance beyond country borders: What really matters. European Finance Review, 5, 141-165.

Mahlberg, B., \& Obersteiner, M. (2001). Remeasuring the HDI by data envelopment analysis. Laxenburg, Austria: International Institute for Applied System Analysis (IIASA).

Maudos, J., Pastor, J. M., Perez, F., \& Quesada, J. (2002). Cost and profit efficiency in European banks. Journal of International Financial Markets, Institutions and Money, 12, 33-58.

McKinnon, R. I. (1973). Money and capital in economic development. Washington D.C.: Brookings Institution.

Pastor, J., Perez, F., \& Quesada, J. (1997). Efficiency analysis in banking firms: An international comparisons. European Journal of Operational Research, 98, 396-408.

Pastor, J. T., Knox Lovell, C., \& Tulkens, H. (2006). Evaluating the financial performance of bank branches. Annals of Operations Research, 145(1/July), 321-337.

Peristiani, S. (1997). Do mergers improve the x-efficiency and scale efficiency of U.S. banks? Evidence from the 1980s. Journal of Money, Credit, and Banking, 29(3), 326-337.

Roll, Y., \& Golany, B. (1993). Alternate methods of treating factor weights in DEA. OMEGA, 21(1), 99-109.

Ruthenberg, D., \& Elias, R. (1996). Cost economies and interest rate margins in a unified European banking market. Journal of Economics and Business, 48, 231-249.

Sathye, M. (2005). Technical efficiency of large bank production in Asia and the Pacific. Multinational Finance Journal, 9(1-2), 1-22.

Schaffnit, C., Rosen, D., \& Paradi, J. C. (1997). Best practice analysis of bank branches: An application of DEA in a large Canadian bank. European Journal of Operational Research, 98, 269-289.

Schumpeter, J. A. (1911). The theory of economic development. Cambridge, M.A.: Havard University Press.

Seiford, L. M., \& Zhu, J. (2002). Modeling undesirable factors in efficiency evaluation. European Journal of Operational Research, $142,16-20$.

Shaw, E. S. (1973). Financial deepening in economic development. New York: Oxford University Press.

Sherman, D. H., \& Gold, F. (1985). Bank branches operating efficiency: Evaluation with Data Envelopment Analysis. Journal of Banking and Finance, 9, 297-315.

Tobin, J. (1958). Estimation of relationships for limited dependent variables. Econometrica, 26(1), 24-36.

WEF. (2010). The financial development report 2010. Geneva, Switzerland: World Economic Forum.

Zhu, J. (2001). Super-efficiency and DEA sensitivity analysis. European Journal of Operational Research, 129, 443-455.

\section{Appendix A}

Table A1

Countries' Data

\begin{tabular}{llrlrrrrrrr}
\hline Country & $y 1$ & \multicolumn{1}{c}{$y 2$} & $y 3$ & \multicolumn{1}{c}{$y 4$} & \multicolumn{1}{c}{$y 5$} & \multicolumn{1}{c}{$y 6$} & \multicolumn{1}{c}{$y 7$} & $y 8$ & $y 9$ & $y 10$ \\
\hline Albania & 0.77 & 66.88 & 0.74 & 2.37 & 2.11 & 0.00 & 9.90 & 0.24 & 16.70 & 3.00 \\
Angola & 0.24 & 9.34 & 0.24 & 9.58 & 0.60 & 0.00 & 2.50 & 0.23 & 5.34 & 4.00 \\
Argentina & 0.18 & 24.47 & 0.20 & 14.91 & 10.01 & 100.00 & 34.30 & 0.18 & 20.60 & 0.00 \\
Armenia & 0.20 & 16.66 & 0.12 & 1.37 & 7.59 & 34.50 & 4.40 & 0.22 & 18.90 & 3.00 \\
Australia & 1.29 & 143.75 & 1.14 & 64.18 & 29.86 & 100.00 & 0.00 & 0.24 & 22.80 & 4.00 \\
Bangladesh & 0.54 & 59.38 & 0.51 & 0.06 & 4.47 & 0.00 & 0.90 & 0.24 & 12.10 & 3.00 \\
Bolivia & 0.32 & 55.24 & 0.38 & 4.80 & 1.53 & 33.90 & 11.60 & 0.21 & 19.00 & 2.00 \\
Botswana & 0.19 & -11.17 & 0.58 & 9.00 & 3.77 & 51.90 & 0.00 & 0.22 & 0.00 & 4.00 \\
Brazil & 0.91 & 117.85 & 0.66 & 17.82 & 14.59 & 59.20 & 23.70 & 0.14 & 20.20 & 2.00 \\
Bulgaria & 0.85 & 66.74 & 0.77 & 29.79 & 13.87 & 6.20 & 34.80 & 0.25 & 20.90 & 3.00 \\
Canada & 1.40 & 178.07 & 1.04 & 135.23 & 45.60 & 100.00 & 0.00 & 0.24 & 22.20 & 4.00 \\
Chile & 0.78 & 115.92 & 0.55 & 24.03 & 9.39 & 33.90 & 32.90 & 0.23 & 22.30 & 2.00 \\
Colombia & 0.51 & 43.26 & 0.22 & 9.60 & 8.74 & 60.50 & 0.00 & 0.21 & 19.30 & 2.00 \\
Costa Rica & 0.49 & 53.90 & 0.25 & 12.83 & 9.59 & 56.00 & 24.30 & 0.15 & 21.80 & 2.00 \\
Croatia & 0.90 & 75.09 & 0.77 & 40.10 & 23.36 & 77.00 & 0.00 & 0.24 & 18.40 & 3.00 \\
Czech Republic & 0.67 & 57.98 & 0.62 & 19.57 & 11.15 & 73.10 & 4.90 & 0.24 & 20.00 & 3.00 \\
Denmark & 2.42 & 211.45 & 0.72 & 52.39 & 37.63 & 5.20 & 0.00 & 0.23 & 3.30 & 3.00 \\
\hline
\end{tabular}


(Table A1 continued)

\begin{tabular}{|c|c|c|c|c|c|c|c|c|c|c|}
\hline Country & $y 1$ & $y 2$ & $y 3$ & $y 4$ & $y 5$ & $y 6$ & $y 7$ & $y 8$ & $y 9$ & $y 10$ \\
\hline Dominican Republic & 0.22 & 39.06 & 0.21 & 15.08 & 6.00 & 46.10 & 29.70 & 0.13 & 19.80 & 3.00 \\
\hline Ecuador & 0.28 & 19.76 & 0.28 & 6.32 & 9.30 & 46.00 & 37.20 & 0.22 & 20.80 & 2.00 \\
\hline Egypt, Arab Rep. & 0.56 & 77.70 & 0.75 & 1.78 & 3.62 & 8.20 & 2.50 & 0.22 & 8.50 & 3.00 \\
\hline El Salvador & 0.42 & 49.94 & 0.42 & 11.07 & 4.62 & 94.60 & 21.00 & 0.23 & 20.50 & 3.00 \\
\hline Estonia & 1.18 & 97.26 & 0.48 & 57.70 & 15.19 & 20.60 & 0.00 & 0.17 & 21.40 & 3.00 \\
\hline Georgia & 0.40 & 32.87 & 0.22 & 1.17 & 3.14 & 12.20 & 0.00 & 0.18 & 19.20 & 3.00 \\
\hline Guatemala & 0.44 & 40.11 & 0.37 & 20.20 & 10.12 & 28.40 & 16.90 & 0.01 & 20.90 & 4.00 \\
\hline Hungary & 0.90 & 80.70 & 0.50 & 29.40 & 28.25 & 10.30 & 0.00 & 0.00 & 20.30 & 2.00 \\
\hline India & 0.69 & 68.35 & 0.70 & 7.29 & 10.64 & 10.20 & 0.00 & 0.24 & 21.00 & 3.00 \\
\hline Indonesia & 0.29 & 36.75 & 0.33 & 4.84 & 8.44 & 0.00 & 22.00 & 0.23 & 20.10 & 3.00 \\
\hline Israel & 0.95 & 82.16 & 0.87 & 18.81 & 14.74 & 89.80 & 0.00 & 0.24 & 21.80 & 3.00 \\
\hline Japan & 1.48 & 379.30 & 1.80 & 113.75 & 9.98 & 76.20 & 0.00 & 0.25 & 21.60 & 3.00 \\
\hline Jordan & 1.29 & 114.92 & 1.09 & 9.38 & 10.02 & 0.00 & 1.00 & 0.24 & 19.10 & 3.00 \\
\hline Kazakhstan & 0.89 & 33.51 & 0.39 & 7.01 & 2.47 & 29.50 & 0.00 & 0.23 & 18.20 & 3.00 \\
\hline Kenya & 0.29 & 40.09 & 0.29 & 0.99 & 1.38 & 2.30 & 0.00 & 0.21 & 14.30 & 2.00 \\
\hline Korea, Rep. & 1.21 & 112.32 & 0.59 & 90.03 & 13.40 & 93.80 & 0.00 & 0.25 & 22.20 & 3.00 \\
\hline Kuwait & 0.81 & 74.92 & 0.71 & 19.69 & 8.27 & 30.40 & 0.00 & 0.23 & 20.20 & 3.00 \\
\hline Lithuania & 0.73 & 64.37 & 0.36 & 28.78 & 3.39 & 18.40 & 12.10 & 0.24 & 18.70 & 3.00 \\
\hline Macedonia, FYR & 0.55 & 42.70 & 0.56 & 49.97 & 26.79 & 0.00 & 28.10 & 0.22 & 16.50 & 3.00 \\
\hline Malaysia & 0.99 & 115.54 & 1.09 & 16.44 & 9.80 & 82.00 & 48.50 & 0.24 & 18.50 & 3.00 \\
\hline Mauritius & 0.88 & 111.78 & 0.86 & 22.04 & 11.92 & 0.00 & 36.80 & 0.24 & 2.50 & 4.00 \\
\hline Moldova & 0.49 & 39.76 & 0.45 & 236.07 & 10.07 & 0.00 & 0.00 & 0.21 & 18.10 & 4.00 \\
\hline Morocco & 0.91 & 95.54 & 0.94 & 9.68 & 15.80 & 14.00 & 0.00 & 0.25 & 17.30 & 3.00 \\
\hline Mozambique & 0.22 & 14.14 & 0.29 & 4.90 & 2.92 & 0.00 & 2.30 & 0.20 & 20.50 & 3.00 \\
\hline New Zealand & 1.55 & 156.45 & 0.96 & 50.36 & 28.04 & 100.00 & 0.00 & 0.25 & 1.70 & 4.00 \\
\hline Nigeria & 0.45 & 26.73 & 0.26 & 18.63 & 6.42 & 0.00 & 0.00 & 0.23 & 17.00 & 3.00 \\
\hline Panama & 0.86 & 85.41 & 0.88 & 16.19 & 12.87 & 45.90 & 0.00 & 0.19 & 21.60 & 3.00 \\
\hline Peru & 0.21 & 18.51 & 0.26 & 5.85 & 4.17 & 31.80 & 23.00 & 0.23 & 21.10 & 3.00 \\
\hline Poland & 0.55 & 60.06 & 0.42 & 17.31 & 8.17 & 68.30 & 0.00 & 0.24 & 18.90 & 3.00 \\
\hline Romania & 0.52 & 40.91 & 0.32 & 12.47 & 13.76 & 30.20 & 5.70 & 0.18 & 9.50 & 3.00 \\
\hline Russian Federation & 0.49 & 26.03 & 0.36 & 6.28 & 2.24 & 14.30 & 0.00 & 0.18 & 19.50 & 2.00 \\
\hline Saudi Arabia & 0.55 & 9.42 & 0.53 & 14.70 & 5.36 & 17.90 & 0.00 & 0.25 & 21.90 & 4.00 \\
\hline Sierra Leone & 0.09 & 7.35 & 0.15 & 1.14 & 2.76 & 0.00 & 0.00 & 0.16 & 0.00 & 3.00 \\
\hline Singapore & 1.10 & 79.17 & 1.18 & 37.93 & 9.13 & 40.30 & 0.00 & 0.26 & 21.90 & 4.00 \\
\hline Slovak Republic & 0.55 & 53.80 & 0.49 & 29.21 & 10.28 & 44.00 & 1.40 & 0.24 & 20.10 & 3.00 \\
\hline South Africa & 0.95 & 215.47 & 0.67 & 17.50 & 5.99 & 54.70 & 0.00 & 0.22 & 19.40 & 4.00 \\
\hline Sweden & 1.40 & 133.43 & 0.57 & 29.56 & 21.80 & 100.00 & 0.00 & 0.25 & 22.30 & 2.00 \\
\hline Switzerland & 1.89 & 180.59 & 1.31 & 70.60 & 37.99 & 22.50 & 0.00 & 0.23 & 22.80 & 3.00 \\
\hline Thailand & 0.84 & 145.65 & 0.79 & 17.05 & 7.18 & 32.90 & 0.00 & 0.24 & 17.60 & 2.00 \\
\hline Tunisia & 0.62 & 72.04 & 0.52 & 17.69 & 15.51 & 0.00 & 19.90 & 0.24 & 7.80 & 3.00 \\
\hline Turkey & 0.51 & 52.54 & 0.42 & 18.00 & 8.50 & 42.90 & 15.90 & 0.22 & 19.70 & 2.00 \\
\hline Uganda & 0.22 & 11.45 & 0.20 & 0.70 & 0.53 & 0.00 & 0.00 & 0.20 & 21.10 & 3.00 \\
\hline United Kingdom & 2.08 & 211.35 & 1.71 & 42.45 & 18.35 & 100.00 & 0.00 & 0.25 & 21.70 & 3.00 \\
\hline United States & 0.73 & 271.64 & 0.83 & 120.94 & 30.86 & 100.00 & 0.00 & 0.22 & 20.30 & 2.00 \\
\hline Venezuela, RB & 0.38 & 20.49 & 0.39 & 16.60 & 4.41 & 0.00 & 0.00 & 0.21 & 21.40 & 3.00 \\
\hline Vietnam & 1.24 & 94.99 & 0.93 & 15.36 & 3.42 & 0.00 & 19.00 & 0.25 & 2.00 & 3.00 \\
\hline Yemen, Rep. & 0.13 & 11.29 & 0.21 & 2.75 & 1.97 & 0.00 & 0.20 & 0.25 & 18.00 & 3.00 \\
\hline
\end{tabular}

Note. $y 1, y 2, \ldots, y 10$ are respectively referred to ten factors in Table 3. 
Table A2

Dynamic DEA Efficiencies

\begin{tabular}{|c|c|c|c|c|c|}
\hline Rank & Country & DSW score & Rank & Country & DSW score \\
\hline 1 & Moldova & 1.000 & 33 & Thailand & 0.961 \\
\hline 2 & Malaysia & 1.000 & 34 & India & 0.957 \\
\hline 3 & Japan & 1.000 & 35 & Dominican Republic & 0.955 \\
\hline 4 & Canada & 1.000 & 36 & Croatia & 0.951 \\
\hline 5 & United Kingdom & 1.000 & 37 & Panama & 0.947 \\
\hline 6 & Denmark & 1.000 & 38 & Czech Republic & 0.947 \\
\hline 7 & Mauritius & 1.000 & 39 & Lithuania & 0.944 \\
\hline 8 & Argentina & 1.000 & 40 & Estonia & 0.939 \\
\hline 9 & Switzerland & 1.000 & 41 & Venezuela, RB & 0.939 \\
\hline 10 & United States & 1.000 & 42 & Poland & 0.938 \\
\hline 11 & Chile & 1.000 & 43 & Indonesia & 0.937 \\
\hline 12 & Guatemala & 1.000 & 44 & Jordan & 0.935 \\
\hline 13 & Singapore & 1.000 & 45 & Albania & 0.931 \\
\hline 14 & Macedonia, FYR & 1.000 & 46 & Brazil & 0.930 \\
\hline 15 & South Africa & 1.000 & 47 & Slovak Republic & 0.929 \\
\hline 16 & New Zealand & 1.000 & 48 & Uganda & 0.925 \\
\hline 17 & Australia & 1.000 & 49 & Bangladesh & 0.920 \\
\hline 18 & Bulgaria & 1.000 & 50 & Kuwait & 0.912 \\
\hline 19 & Vietnam & 1.000 & 51 & Turkey & 0.904 \\
\hline 20 & Sweden & 1.000 & 52 & Mozambique & 0.901 \\
\hline 21 & Korea, Rep. & 1.000 & 53 & Kazakhstan & 0.893 \\
\hline 22 & El Salvador & 1.000 & 54 & Nigeria & 0.893 \\
\hline 23 & Botswana & 1.000 & 55 & Hungary & 0.890 \\
\hline 24 & Saudi Arabia & 1.000 & 56 & Armenia & 0.870 \\
\hline 25 & Angola & 1.000 & 57 & Bolivia & 0.867 \\
\hline 26 & Ecuador & 0.985 & 58 & Egypt, Arab Rep. & 0.863 \\
\hline 27 & Yemen, Rep. & 0.984 & 59 & Russian Federation & 0.855 \\
\hline 28 & Costa Rica & 0.980 & 60 & Colombia & 0.846 \\
\hline 29 & Morocco & 0.972 & 61 & Georgia & 0.842 \\
\hline 30 & Tunisia & 0.970 & 62 & Kenya & 0.813 \\
\hline 31 & Peru & 0.969 & 63 & Romania & 0.750 \\
\hline 32 & Israel & 0.965 & 64 & Sierra Leone & 0.750 \\
\hline
\end{tabular}

Note. First 25 countries are ranked based on super-efficiency DEA results. 